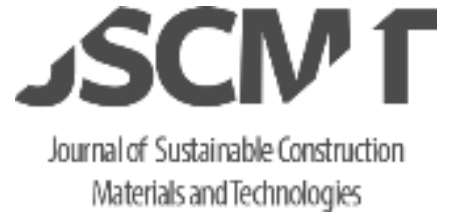

J. Sustain. Construct. Mater. Technol. 3(2) (2018) 230-234

\section{Journal of Sustainable Construction Materials and Technologies}

http://www.eds.yildiz.edu.tr/jscmt

\title{
Infrastructure Projects In Turkey and Innovative Implementations In Project Management
}

\author{
İskender Eyüp Ekiz ${ }^{1, *}$ and Mehmet Fatih Altan ${ }^{2}$ \\ ${ }^{1}$ Istanbul Aydin University Institute of Science and Technology, Halit Aydin Campus No:38 \\ Küçükçekmece, Istanbul/Turkey
}

Received February 7, 2018; accepted April 13, 2018

\begin{abstract}
In Turkey, transportation investments have taken the first number on the agenda on the last decades. Tremendeus projects like Kanalistanbul is mnetioned beside many airport projects in Anatolian cities that are existing many urban railway system projects in Istanbul and any other major cities beside high speed railway projects that connects the cities of Turkey by west to east and by south to north. Turkey continues the period of infrastructural establishment and renowation rapidly as a developing country which aims to being one of the biggest economy all over the world. Because of these, project management, management notions, usage of innovative Technologies and organizational structures have a vital role in Turkey which has a dense infrastructure establishment period and gives prority to transportation.
\end{abstract}

Keywords: Civil Engineering Projects, Information Technologies, Infrastructure, Project Management, Transportation Infrastructures

\section{Introduction}

In the last quarter of the 20th century, we see that important technological advances in the transportation sector have increased the efficiency in international trade and that there is a structural change that must be taken seriously in the world trade model. So much so that the interaction of transport and globalization processes has also changed the geography of international transport and reduced the importance of national boundaries. Processes of economic integration, This development reveals a model of global economy which is more complicated and interdependence is increasing. In 2003, the volume of international trade increased by more than 2 folds after 1950, to $15 \%$ of global Gross Domestic Product (GDP) [1].

The breakthrough in railway and maritime transportation in the first years of the Republic in our country has made important contributions to the development of trade and the industry, in that years the production and consumption of the agricultural population, which is the locomotive of the country's economy, became more involved.

\footnotetext{
${ }^{*}$ Corresponding Author:

E-mail: iskendereyupekiz@gmail.com (İ. Ekiz)

https://doi.org/10.29187/jscmt.2018.24
} 
Turkey, the world and the Middle East with $65 \%$ to $35 \%$ of oil reserves and natural gas reserves of Central Asian countries and the importers of oil and natural gas are among the European countries. From here, it can be said that the transportation corridors passing through our country and linking the Euro-Caspian routes are of great importance both for the distribution of energy and for the transportation of freight and passengers [2].

\section{Project Management Information System}

In larger projects, the use of project management methods in practice is only possible with the support of Project Management Information System (PMIS), depending on high demands. Project managers; planning, monitoring, continuous evaluation of project implementation and a range of applications recommended in a wide range of functions in the field of work appraisal [3]. An important function proposed by the Project Management Information System (PMIS); Depending on the projects to be continued, it is possible to share data with the project team and around. Project Management Information System (PDBS) applications are first-hand designs to support project management, so it is important to note how appropriate the support of the methods defined in project management theory is, how well each step in the project life cycle can be supported by software applications, and how the qualitysuch as the level of qualification.

An increase in project success rate through the use of Project Management Information System (PDBS); have been confirmed by relevant studies. In addition, using project management methods and processes by using Project Management Information System (PDBS) helps to increase project success rate. For this reason, the applicability of Project Management Information System (PDBS) software applications to project management methods in practice is required.

The Project Management Institute (PMI) standard in 2004 defined the project as: "A unique product, service is a temporary effort to bring out the result." The Project Management Association (APM) PRINCE 2 standard defines the project in 2012 as follows: 'A temporary and unique effort undertaken to achieve a desired outcome'. Thus, the main points emphasized in both standards are; the temporal duration of the plant and the uniqueness of the output of the applied plant [4].

Project management theory and its application; A number of methods, tools and techniques are proposed to strengthen project management. In the concept phase; feasibility study, benefit-cost analysis, financial analysis and economic efficiency evaluation of the project and logical framework can be used to identify a project as precisely as possible and to calculate its benefits. During the planning phase; (APM, 2012), Business Analysis Structure (PMI, 2004), Network Analysis Method (Critical Path Method, Meta Potential Method, Critical Path / Cost Method, Program Evaluation and Review Technique, Graphical Evaluation and Inspection Technique) can be sensitively detected by the Gantt Schematic (PMI, 2004) and the Critical Series Method.

\section{Construction Knowledge Models In Project Management}

Building information modeling (BIM) has begun to evolve into a comprehensive collaborative process in the construction sector. Despite its short history, BIM (YBM) has developed rapidly in the last decade. This is largely due to the capabilities of the construction sector. BIM can bring a common language among all the components and departments of a project and make them an integrated team. The BIM approach largely overlaps with integrated project delivery systems. The role of BIM as a coordinator in the project system is quite similar to that of a project mission. BIM integrates different disciplines with effective communication, analyzes the project system in terms of constructability, calculates the cost and time at any moment of the project with numerical inferences, draws a large picture of the projects through visualization and brings cooperation teams to the scene. All this is the whole of what a project crew needs to do at different scales throughout a project life cycle.

The concept of BIM was put forward by the Georgia Institute of Technology at the end of the 1970s and quickly developed. This development; companies looking for competence in the use of BIM to integrate construction projects and management processes, and increasingly careful construction teams. The concept of building information modeling was first used in 2002 to define the management of visual design, construction and facilities [4]. 
Construction projects; in terms of quantity, variety and cost, they constitute the main part of the projects in all disciplines. United States (US) Population Administration; By 2013, the construction sector in the country has reached a volume of 874 billion US dollars. These can range from small housing and retail projects to multifunctional mega-projects. It is not necessary to say that construction management is a necessity for construction projects of all sizes. Management of construction projects; it requires modern management knowledge such as the understanding of the entire construction process.

Integrated project delivery (IPD); is an emerging approach to delivery projects that integrates efforts in different disciplines and integrates all stakeholders, including project managers, designers, engineers, systems and applications, within a collaboration process. IPD optimizes project value by improving efficiency at all stages. The IPD incorporates all the components into the project and brings them into a cohesive team. Along with IPD, all components concentrate on the mainstream outputs of the project for individual purposes. To have a more effective approach, the BIM instruments provide an integrated and unified way of communicating the entire team and visualizing and analyzing highly complex project information. Combining and combining detailed information from all components with an integrated model will improve the productivity and manageability of the project team.

Integration management is the first working place of PMBOK and it has the same function as BIM. BIM integrates the documents, plans and efforts of all parties involved in a project. BIM also provides an element-based floor so that the different elements of a building can be categorized and the resulting project can be divided into different groups in the direction of goal management. Another feature of the BIM is the time and cost, in other words the competence of $4 \mathrm{D}$ and 5D management. This is similar to the areas of project cost and time management in the PMBOK standards. Though buildability does not show all of the risks involved in a construction project, it is also an effective tool in the construction of a project and reduces construction risks. Detection of incompatibility in BIM; as a quality prosesis that performs visual awareness, improvement and analysis of hardware and software incompatibilities. Collaboration and team building at BIM considers human resource management as a project management area. Communication is one of the key features of BIM and facilitates professional relationships among all stakeholders, including project managers, designers and engineers, in a construction project through the creation of effective and direct communication channels. Finally, procurement management is possible through the quantitative action points produced by BIM. In addition, the change in any element is clearly reflected in the time and cost of the work required for procurement. In spite of the advanced editing of project management, BIM is presented as a basic and effective concept parallel to project management information fields [5].

\section{Review}

Since the reciprocal relationships are the fundamental characteristic of BIM, user characteristics influence the effectiveness of BIM. BIM users; all parties and professionals, and therefore the attitudes and opinions of the project managers, especially the project managers as the core of communication channels, should be considered as an effective factor. The level of experience of project managers is directly related to the success of BIM in construction projects. The qualifications and advantages of BIM; It is believed that the users are directly proportional to the level of experience. In various researches; it is suggested that having an experienced BIM project manager on the project team is a key factor in the success of construction projects. The project manager's high BIM knowledge level enhances BIM's competencies from software applications to a holistic understanding of integrating and coordinating all stakeholders and systems in a project. As an advanced competence for construction projects, the BIM knowledge level should be considered internally, while having appropriate experience and knowledge of BIM should be established as a criterion for the receipt of a construction project manager.

Although there has been a significant improvement in the construction sector in the housing sector during the last decade, this situation has remained limited for off-site construction in infrastructure. With related studies; the question of how innovative initiatives such as out-of-site production and BIM can be taken into consideration has been searched and a more precise design, more integration of lifecycle project data and more original technical solutions can be addressed. Analysis; outlined the benefits of out-of-site production in a BIM environment, the current challenges in the supply chain, and offered suggestions on how best to implement the benefits. 
Table 1. Summary of Dynamics and Advantages for BIM and Non-Site Production [6]

\begin{tabular}{|c|c|c|}
\hline BIM & Dynamics and Advantages & Non-Site Production \\
\hline $\begin{array}{l}\text { McGraw-Hill, } 2010 \\
\text { NBS BIM Report, } 2013\end{array}$ & Cost & $\begin{array}{l}\text { Pasquire ve Gibb, } 2002 \\
\text { Gibb ve Isack, } 2003\end{array}$ \\
\hline NBS BIM Report, 2013 & profitability & Pasquire ve Gibb, 2002 \\
\hline NBS BIM Report, 2013 & time & $\begin{array}{l}\text { Pan ve Sindell, } 2011 \\
\text { Pasquire ve Gibb, } 2002 \\
\text { Goodier ve Gibb, } 2007\end{array}$ \\
\hline Kriegel ve Nies, 2008 & $\begin{array}{l}\begin{array}{l}\text { Sustainability } \text { (such as } \\
\text { reduction) }\end{array} \\
\end{array}$ & Pasquire ve Gibb, 2002 \\
\hline $\begin{array}{l}\text { McGraw-Hill, } 2010 \\
\text { NBS BIM Report, } 2013 \\
\text { Nisbet ve Dinesenm } 2010\end{array}$ & productivity & $\begin{array}{l}\text { Pasquire ve Gibb, } 2002 \\
\text { Gibb ve Isack, } 2003\end{array}$ \\
\hline McGraw-Hill, 2010 & Quality & Gibb ve Isack, 2003 \\
\hline
\end{tabular}

\section{Analysis}

Considering the out-of-site manufacturing effects of BIM, most participants expect that the use of off-site manufacturing in the civil engineering sector will increase with the UK government making BIM mandatory by 2016. Some; firmly claim that off-site production would be a loss to this area without the various mechanisms that are not easy to ensure that the design intent is to be structured based on efficient production. It is also claimed that for BIM only, it first designs digital objects precisely and then manufactures them under factory conditions. Others are more cautious at this point, and many parameters exist in determining where and how to use non-production sites, but BIM also points out that the designer is at the point of taking all of these factors into account and helping them to make more informed decision-making. Nevertheless; many things have been clarified at the point that it depends on how the BIM and off-site production are organized and applied on the operated model [6]. In spite of the common view of the participants that BIM positively affects the production on-site, a small number of consultants have stated that BIM can not be a facilitator on non-worksite production because the BIM applies equally to intra-site and offsite operations. The consultants say that off-site production has an increasing performance but that BIM has foresaw the increase in performance with formal entry into the industry.

\section{Outputs}

Both BIM and off-site production are not entirely new as a concept, but within decades there have been changes in the meanings of the concepts in terms of reflecting industrial trends. In the last few years, a number of successful offsite operations have been published and published in a BIM environment. The vast majority of them focus on the housing sector, which is pioneered by the United States (USA). In the UK, early adop- tions are examples of various 
best practices in which the Justice Department implements prison blocks using off-site manufacturing and BIM, with brilliant results. Despite all the high expectations from the literature and some application successes in the housing sector, construction engineering has witnessed a rather limited off-site production practice within BIM. In the course of the research, participants have attempted to identify examples of evidence to demonstrate that BIM has provided, encouraged, promoted, and developed on-site production, but no other evidence from the various key infrastructure projects phases has been provided. The UK government has provided examples of projects using the BIM from the RIBA (UK) Institute of Architecture, which is basically mistaken. Furthermore, based on this principle, various participant examples have been disabled because of the fact that the BIM elements are rarely 3-D or the BIM applications originate for commercial reasons and not because of efficiency [6]. When the participants did not provide evidence, they claimed that their proposals would become true during BIM level 3. The UK government, however, has accepted this statement correctly and adequately. Off-site production; pre-cast concrete elements, tunnels and bridge constructions because of the construction industry has a closer concept for the sector. However, during the data collection process, many parties use terms such as standardization, prefabrication (pre-production) and off-site production not to be fully understood. Scale economies are successful in standardizing BIM and off-site manufacturing staff, which significantly impacts the process, yet one can not automatically direct the other. In this context, some contractors have also been stating that 'besides the need for parametric and logistical flexibility,' standardization is a phase of BIM, but a small part of civil engineering work is standardized '. The confusion between contractors and consultants is not only related to off-site production, but also to BIM terminology.

\section{Conclusion}

Civil engineering sector; in a similar way to the housing sector, to a multidimensional object-oriented design approach. Many of them; this would naturally be exactly the case if the data is being delivered directly to the manufacturer that the object design is shifting to a manufacturing-focused point. Construction sector; is a lowintensity information sector compared to finance banking. Along with that; constructs are complex entities that come from various subsystems and variable elements [7]. Continued confidence in the civil engineering industry in paperbased drawings used as a tool for design and production data records is an obstacle to innovation in off-site production. Theoretically, with the digitization of the data in the construction sector, BIM will increase production on-site, along with the automation expected in the design, production and construction. BIM; making construction data 'machine readable' and making the construction elements possible without human intervention. However, for any technology applied in the industry, a number of factors are taken into account, including staff attitudes, corporate structure and cultures, business unit level between supply chain stakeholders, leadership and senior management support, and company changeability.

\section{References}

1. Ilıcalı, Mustafa, 'Yüksek Hızlı Demiryolu Yatırımlarının Ülke ve Bölgeye Etkisi', Taşıma Dünyası, 2015: 4.

2. Kızıltaş, Mehmet Çağrı, ‘Avrupa Birliği ve Ulaştırma Politikaları', Ulaştırma Dünyası, 2015: 3.

3. Kızıltaş, Mehmet Çağrı, 'Yüksek Hızlı Demiryolu Analizleri’, Ulaştırma Dünyası, 2016: 5.

4. Banwell, H., The placing and management of contracts for building and civil engineering works. HMSO, London, 1964: 3.

5. Bernstein, P.G. and Pittman, J.H., Barriers to the Adoption of Building Information, 2005: 4

6. Bew, M. And Underwood, J., Delivering BIM to the UK Market, in: Handbook of research on building information modelling and construction informatics: concepts and technologies. IGI-Global, New York, 2009, 30-64.

7. Blismas, N.G.,Pendlebury, M.C, Gibb, A.G.F. and Pasquire, C.L., Constraints to the Use of Off-site Production on Construction Projects, Architectural Engineering and Design Management, 1(3), 2005: 153162. 